agriTECH, 41 (4) 2021, 354-361

\title{
Characterization of Old Nipah (Nypa fruticans Wurmb) Fruit Endosperm Flour and Its Application for Gluten-Free Cookies
}

\author{
Risa Nofiani*, Jorion Romengga, Titin Anita Zaharah \\ Department of Chemistry, Mathematics and Natural Sciences Faculty, Tanjungpura University, \\ Jl. Prof. Dr. Hadari Nawawi, Pontianak, West Kalimantan 78124, Indonesia \\ *Corresponding author: Risa Nofiani, Email: risa.nofiani@chemistry.untan.ac.id, rnofiani@yahoo.com
}

Submission: April 8, 2020; Revision: April 13, 2020; Acceptance: November 13, 2020

\begin{abstract}
Old nipah fruit endosperms (ONFEs) contain high carbohydrates that have a potency to be applied to make flour. In this study, we made flour from ONFEF and its cookies. This study aimed to characterize the functional properties of unbleached and bleached old nipah fruit endosperm flour (UONFEF and BONFEF) and to assess the consumer acceptability of ONFEF flour and gluten-free cookies made from UONFEF and BONFEF. UONFEF and BONFEF were prepared from the ONFEs. They were cut, dried and ground, and sieved to obtain the UONFEF. The UONFEF was bleached using $\mathrm{Na}_{2} \mathrm{~S}_{2} \mathrm{O}_{5} 0.4 \%$ for 15 mins then filtered, and the precipitates were dried under the sun. The dried precipitates were sieved to obtain the BONFEF. Both of the flour types were analyzed in terms of their functional properties (bulk density, swelling power, solubility, swelling capacity, water absorption index, and viscosity) and were used to make gluten-free cookies. The following ingredients were prepared to make the the gluten-free cookies: $200 \mathrm{~g}$ of flour (each of the UONFEF, BONFEF, and commercial wheat flour (CWF, Segitiga Biru brand) as a control), $100 \mathrm{~g}$ of margarine, $60 \mathrm{~g}$ egg, $125 \mathrm{~g}$ of fine granulated sugar, and $2 \mathrm{~g}$ of vanillin. Margarine, egg, and fine granulated sugar were mixed using a hand mixer and added with the flour, blended, molded, then baked. Consumer's acceptability of each type of flour and cookies from different types of flour was evaluated using semi-trained panelists. The bleached treatment (the BONFEF) caused differences of the flour, particularly in terms of the physical properties (particle size, color, and odor) from the unbleached treatment and rated the highest score for the overall criteria. Besides, the functional properties of the UONFEF were significantly different $(p<0.05)$ from those of the BONFEF except for the rendement, SP, and viscosity. The gluten-free cookie made from the UONFEF was the most preferred by the panelists. Therefore, the UONFEF can be successfully used as a substitute flour of wheat flour to make cookies.
\end{abstract}

Keywords: Bleaching; flour; functional properties; gluten-free cookies; Nypa fruticans Wurmb

\section{INTRODUCTION}

Nipah (Nypa fruticans Wurmb) or mangrove palm was abundantly found at brackish water swamp from Sri Lanka, the Ganges Delta, Myanmar, Indonesia to New Guinea and Solomon Islands, and northward to the Philippines and Ryukyu Island, and southward to North Queensland, and Nigeria (Tomlinson, 2016). Nipah fruits have been used as foodstuffs such as nipah sugar produced from fresh fruit bunches and salt from old midribs (Subiandono, Heriyanto, \& Karlina, 2016). However, nipah is still categorized as an underutilized plant (Ulyarti, Nazarudin, \& Sari, 2017) with a low economic value.

Nipah fruit endosperm flour (NFEF) contains high carbohydrates $(72-88 \%)$, high fibers $(0.18-22 \%)$, low lipids $(0.08-12 \%)$, and low proteins (2-12\%) (Subiandono et al., 2016; Ulyarti et al., 2017; Nofiani, Romengga, \& Zahara, 2009; Akpabio, Essien, \& Eka, 2007). Nipah fruit endosperm also contains mineral 
elements ( $\mathrm{Mg}, \mathrm{K}, \mathrm{Ca}, \mathrm{Na}, \mathrm{Mn}, \mathrm{Fe}$, and $\mathrm{Cu}$ ), vitamin $A$, and C (Akpabio et al., 2007). Anti-nutrients (HCN, tannin, phytic acid, oxalate) are also detected in old nipah fruit endosperm, but they are still within the tolerable amount for humans (Akpabio et al., 2007). Young nipah fruit endosperm extracts can be used as a natural antioxidant due to high total phenolics, total flavonoid contents, and antioxidant capacities (Prasad et al., 2013). Therefore, nipah fruit endosperm can be accepted as foodstuff, particularly flour.

NFEF has been reported for its application as a composite flour between NFEF and commercial wheat flour (CWF) to make cakes and biscuits. The best butter cake based on the overall sensory score was made from composite CWF and NFEF with a ratio of 60:40 (Mursyid \& Surhaini, 2018). Biscuits made from composites between old NFEF (37.5\%) and CWF (62.5\%) could also be accepted by panelists (Akpabio et al., 2007). However, a cookie made from only NFEF has not been reported yet.

Cookies are popular snacks in human consumption. Most cookies are generally made from CWF. But, cookies made from CWF cannot be consumed by celiac disease patients. Celiac disease is an immune disease in which people cannot consume gluten foods containing wheat, rye, and barley. Endosperms from nipah fruit contain a high carbohydrate content that has potency as flour to replace CWF to make gluten-free cookies (Nofiani et al., 2009; Subiandono et al., 2016). The endosperms from ONFs were chosen to make nipah flour in this study. The ONFs can be determined by the form of haustorium in the fruits (Tomlinson, 2016). The endosperm from the ONFs was used to make flour with and without bleaching treatment $\left(\mathrm{Na}_{2} \mathrm{~S}_{2} \mathrm{O}_{5} \quad 0.4 \%\right)$ to obtain unbleached and bleached old nipah fruit endosperm flour (UONFEF and BONFEF). Then, both of the types of flour were used to make cookies. These types of flour were characterized for their functional properties and evaluated in terms of the consumer's acceptability. Each cookie made from different flour was also evaluated in terms of the consumer's acceptability.

\section{MATERIALS AND METHODS}

\section{Material}

The materials used in this study were old nipah fruits (ONFs) which were collected from Parit Mayor Subdistrict (East Pontianak District) and Antibar Subdistrict (Mempawah Hilir District) West Kalimantan, $\mathrm{Na}_{2} \mathrm{~S}_{2} \mathrm{O}_{5}$ (food grade), margarine (Blue Band brand), eggs, vanillin (food grade), and commercial wheat flour (Segitiga Biru brand, $11-12.5 \%$ of protein). The CWF was obtained from Bogasari, Indonesia.

\section{Equipment}

The equipment used in this study were centrifuge, copra grinding machine, pycnometer, light microscope (Primo Star, Zeiss), and Ostwald viscometer.

\section{Preparation of Nipah Flour}

Old nipah fruit endosperm flour (ONFEF) was prepared by two treatments, namely unbleached and bleached. The ONFEF was prepared from old nipah fruit endosperm fruits (ONFEs). The endocarp of each ONFE was scraped, then rinsed, cut, and dried under the sun for 6-8 hours to reduce the water content, approximately $40 \%$ from wet ONFEF. Dried-ONFE was ground with a copra grinding machine to obtain flour. The flour was sieved with a 200 mesh size and referred to as the unbleached ONFEF (UONFEF).

Bleached ONFEF was prepared by soaking the UONFEF in sodium metabisulphite $(0.4 \%)$ and mixed. After 15 minutes, the mixture was filtered and rinsed with water twice, and the precipitates were dried under the sun. Finally, the dried precipitates were sieved with a 200 mesh size to obtain the BONFEF. Rendement of both of the types of flour was calculated as Equation 1.

Rendement $(\%)=\frac{\text { Flour weight }}{\text { Dried fruit endosperm weight }} \times 100 \%$

Furthermore, each flour was put on a glass slide and added a drop of iodine solution (0.05\%). After drying, a coverslip was put on the surface of the stained flour and its particle was observed using a light microscope with a magnification of $100 \mathrm{X}$.

\section{Functional Properties}

\section{Swelling power (SP) and solubility (Sol)}

SP and Sol were carried out following a modified procedure described by Leach et al. (Leach \& Schoch, 1960; Anderson, Conway, \& Peplinski, 1970). A two g of nipah flour was resuspended in $178 \mathrm{~mL}$ of deionized water, shaken using a shaking water bath at 200 RPM and $80{ }^{\circ} \mathrm{C}$. After 30 minutes, the suspension was centrifuged at $1.731 \mathrm{xg}$ for 15 minutes. The pellet was air-dried for 10 mins and weighed until constant weight. The supernatant was carefully transferred into a new container, dried, and weighed until constant weight. The SP and Sol were calculated as Equation 2 and 3.

$$
\begin{aligned}
& \text { Sol }(\%)=\frac{\text { dry supernatant }(g)}{\text { dry sample }(g)} \times 100 \% \\
& S P\left(\frac{g}{g}\right)=\frac{\text { wet pellet }(g)}{\text { dry sample }(g) \text {-dry supernatant }(g)}
\end{aligned}
$$




\section{Swelling capacity (SC)}

SC was determined based on the method described by Okaka and Potter (Okaka \& Potter, 1977; Chandra et al., 2015). Ten $\mathrm{g}$ of sample was poured into a cylinder, and its volume was recorded. Distilled water was added to the sample until a total volume of $100 \mathrm{~mL}$, stirred using a magnetic stirrer at 200 RPM with a certain duration $(1,5,10,15,25,30,45$, and 60 mins). The difference between the final and initial volume was calculated as swelling capacity.

\section{Water absorption capacity (WAC)}

WAC was determined based on Anderson et al. (Anderson et al., 1970; Bamigbola, Awolu, \& Oluwalana, 2016). Nipah flour ( $5 \mathrm{~g}$ ) was resuspended with $30 \mathrm{ml}$ of distilled water, stirred for 30 mins then centrifuged at $1.731 \times \mathrm{g}$ for 15 mins. The supernatant was carefully decanted, and the sediment sample was weighed. The WAC was determined as Equation 4.

WAC $(\%)=\frac{\text { wet sample }(g)}{\text { dry sample }(g)} \times 100 \%$

\section{Bulk density (BD)}

BD was determined using a pycnometer (Bradley, 2014). The sample or distilled water was poured into a pycnometer $10 \mathrm{~mL}$ then each sample was weighed. BD was calculated as Equation 5.

$B D(\%)=\frac{\text { Sample weight }}{\text { Sample volume }} \times 100 \%$

\section{Viscosity}

Viscosity was determined using Ostwald viscometer. A $100 \mathrm{~mL}$ of $1 \%$ sample solution or water was poured into Ostwald viscometer up to mark $A$. The flow time of the sample or water from mark $A$ to mark $B$ was recorded. Viscosity ( $\eta$ ) was calculated as Equation 6.

$\eta=\frac{\rho_{\text {sample }} \cdot t_{\text {sample }}}{\rho_{\text {water }} \cdot t_{\text {water }}} \times \eta_{\text {water }}$

\section{Statistical Analysis}

Different treatments of nipah flour (unbleached and bleached treatment) were calculated by a paired-sample T-test technique with a 95\% $(p<0.05)$ confidence level using The IBM SPSS statistics 23. All the experiments were repeated in triplicates.

\section{Cookie formulation}

Cookies were prepared using a recipe with ingredients as follows: margarine $(100 \mathrm{~g})$, an egg (60 g), fine granulated sugar (125 g), vanillin $(2 \mathrm{~g})$, and flour $(200 \mathrm{~g})$. The flour used in this experiment was UONFEF, BONFEF, and CWF as a control. Margarine, egg, and fine granulated sugar were mixed using a hand mixer until smooth. The dough was added with flour, blended and rolled out into a thin sheet of uniform thickness then cut into the desired shape ( $5 \mathrm{~cm}$ diameter). Finally, it was baked at $180^{\circ} \mathrm{C}$ until light golden brown.

\section{Sensory Evaluation}

Nipah flour and cookies made from different types of flour were evaluated in terms of their acceptability by involving 20 semi-trained panelists. A nine-point hedonic scale was used to assess the overall acceptability based on color, texture, aroma, taste criteria. The data were analyzed using the Analytical Hierarchy Process (AHP) model.

\section{RESULT AND DISCUSSION}

\section{Flour Preparation}

The endosperm of the ONFs used in the flour preparation was the endocarp-free endosperm although the endocarp was hard to be removed from the endosperm. Furthermore, the endocarp-free endosperm dried under the sun caused brownish endocarp-free endosperm, which was probably caused by the browning reaction. The endosperm showed a hard texture, so it was difficult to be ground using a hand blender or a grater. Therefore, it was ground using a copra grinding machine and sieved to obtain the UONFEF; some was then bleached to obtain the BONFEF (Figure 1). The UONFEF had rancid odor and brownish color, which was probably caused by the browning reaction during the drying.
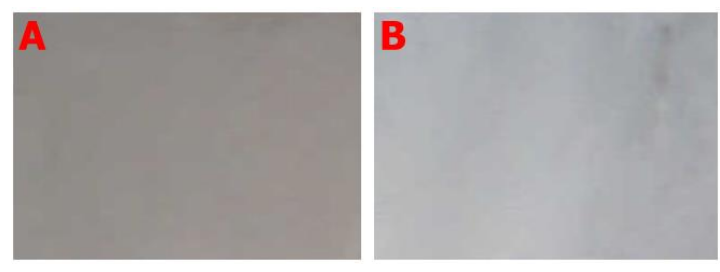

Figure 1. Nipah flour (A) UONFEF and (B) BONFEF

The soaking during the bleaching treatment partially leached out proteins, lipids, ashes, simple carbohydrates, particularly compounds, causing unpleasant odor and brown from the surface of the flour particle. As a result, the color of the UONFEF changed from light brown to white (Figure 1) and the unpleasant odor no longer 

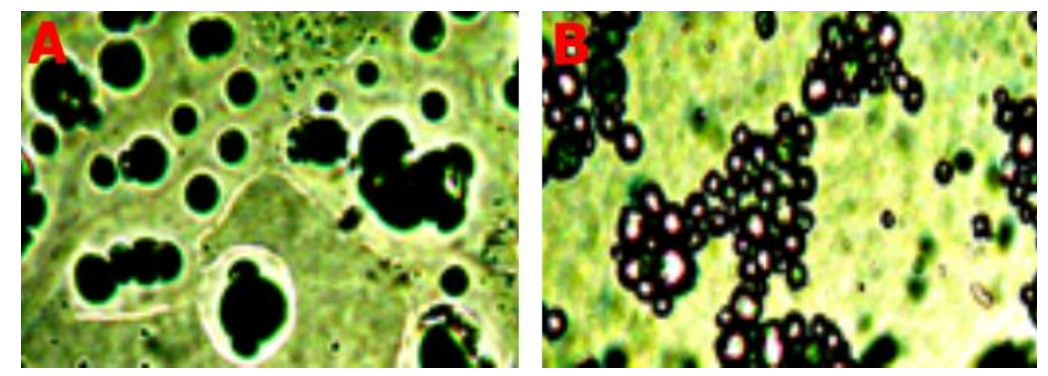

Figure 2. Micrograph of stained nipah flour using a light microscope with a magnification of 100x (A) UONFEF and (B) BONFEF

existed, making it odorless flour. It also reduced the particle size of the flour, causing more particles to pass through the sieving stage (Figure 2). As a result, the rendement percentage of the BONFEF (78\%) was higher than that of the UONFEF (77\%). The bleaching treatment successfully improved the ONFEF quality, particularly its color and odor.

Consumer's acceptability of both the UONFEF and the BONFEF was assessed by a sensory evaluation using four criteria (taste, color, texture, and aroma). The dominant criteria were arranged based on the panelists' opinion. The dominant criteria from high to low scores were taste, color, texture, and aroma, respectively (Table 1). The sensory evaluation of the flours revealed that the BONFEF obtained the highest criteria score for all of the criteria, followed by the UONFEF and CWF, respectively (Table 1 ). The consistency ratio (CR) was calculated to identify possible errors in the panelists' assessments. The consistency ratio of the panelists was 0 or less than $10 \%$, meaning that the panelists were consistent with their choice.

\section{Functional Properties of Nipah Flour}

Different flour sources cause different physical, chemical compositions, and processing, affecting their properties and functionality. Therefore, the UONFEF and the BONFEF have characterized their functional properties such as $\mathrm{SP}$, Sol, SC, WAC, BD, and viscosity
(Table 2).

$\mathrm{SP}$ value describes the extent to which flour, particularly starch granules, can bind water to show its expansion or hydration capacity to form swollen starch granules (Buckman, Oduro, Plahar, \& Tortoe, 2018; Falade \& Okafor, 2015). The ratio, intra- and intermolecular interactions, molecular weights of amylose and amylopectin in the starch, packing of starch granules with proteins and lipids are factors affecting SP value (Mir \& Bosco, 2014). A high amylopectin content can increase SP value because there are more interactions between amylopectin hydroxyl groups and the hydrogen of water. On the contrary, a high amylose and lipid content can reduce SP value (Sasaki \& Matsuki, 1998). The SP values of the UONFEF and the BONFEF at 80 ${ }^{\circ} \mathrm{C}$ were $20.3 \%$ and $21.9 \%$, respectively, which showed insignificant difference $(p>0.05)$ between the two types of flour (Table 2). Bleaching treatment probably breaks hydrogen bonds in the packing of starch granules, causing uptake of water by hydrogen bonds and water absorption by non-starch polysaccharides and proteins (Yu, Ma, Menager, \& Sun, 2012)

Sol in the food system is defined as the ability of solid, liquid, or gas-producing food to be dissolved in the liquid, gas, or solid solvent. The amount of the flour that dissolves into water or solution is called flour solubility (Godswill, Somtochukwu, \& Kate, 2019). SP and Sol can be used to describe the extent of the interaction between the starch chains in the amorphous and crystalline

Table 1. Sensory evaluation of nipah flour

\begin{tabular}{lccccc}
\hline \multirow{2}{*}{ Sample } & \multicolumn{4}{c}{ Criteria Score of } & \multirow{2}{*}{ Overall criteria score } \\
\cline { 2 - 5 } & Taste & Color & Aroma & Texture & 0.12 \\
CWF & 0.10 & 0.17 & 0.10 & 0.11 & 0.26 \\
UONFEF & 0.29 & 0.24 & 0.29 & 0.23 & 0.61 \\
BONFEF & 0.61 & 0.59 & 0.61 & 0.66 & \\
Dominant criteria & 0.32 & 0.29 & 0.15 & 0.24 & \\
\hline
\end{tabular}

CWF: Commercial wheat flour; UONFEF: Unbleached old nipah fruit endosperm flour; BONFEF: Bleached old nipah fruit endosperm flour 
Table 2. Functional properties of old nipah fruit endosperm flour

\begin{tabular}{lccccccc}
\hline Sample & $\begin{array}{c}\text { Rendement } \\
(\%)\end{array}$ & $\begin{array}{c}\text { Swelling } \\
\text { power } \\
(\%)\end{array}$ & $\begin{array}{c}\text { Optimum } \\
\text { time of SC } \\
(\mathrm{min})\end{array}$ & $\begin{array}{c}\text { Solubility } \\
(\%)\end{array}$ & $\begin{array}{c}\text { WAC } \\
(\%)\end{array}$ & $\begin{array}{c}\mathrm{BD} \\
(\mathrm{g} / \mathrm{mL})\end{array}$ & $\begin{array}{c}\text { Viscosity } \\
(\text { Pa.s })\end{array}$ \\
\hline UONFEF & $77.30 \pm 0.46^{\mathrm{a}}$ & $20.30 \pm 0.43^{\mathrm{a}}$ & $5^{\mathrm{a}}$ & $0.7 \pm 0.00^{\mathrm{a}}$ & $145.11 \pm 0.00^{\mathrm{a}}$ & $76.86 \pm 2.70^{\mathrm{a}}$ & $(11.91 \pm 0.28) 10^{-4 \mathrm{a}}$ \\
BONFEF & $78.05 \pm 0.31^{\mathrm{a}}$ & $21.90 \pm 0.62^{\mathrm{a}}$ & $10^{\mathrm{b}}$ & $1.2 \pm 0.00^{\mathrm{b}}$ & $145.63 \pm 0.01^{\mathrm{b}}$ & $55.72 \pm 2.04^{\mathrm{b}}$ & $(11.47 \pm 0.09) 10^{-4 \mathrm{a}}$ \\
\hline
\end{tabular}

The values presented in mean \pm standard deviation in the same vertical column with different superscript letters showed a significant difference $(p<0.05)$. UONFEF: unbleached old nipah fruit endosperm flour. BONFEF: bleached old nipah fruit endosperm flour. $\mathrm{n}=3$

domains and the association bonds in starch granules (Amoo, Dufie, \& Ibok, 2014). The UONFEF and the BONFEF showed low solubility, namely $0.7 \%$ dan $1.2 \%$, respectively (Table 2 ). However, both the Sol of the two types of the flour was still categorized as a soluble flour because the value was greater than $0.1 \mathrm{~g} / 100 \mathrm{~mL}$ of the solvent (Godswill et al., 2019). Solubility value can describe the digestibility level of food, which higher solubility of food the higher digestibility level. Different flour processings in this Sol study exhibited a significant difference $(p<0.05)$. One of the factors that contributes to solubility is particle size; the smaller the particle size, the quicker the dissolution. The other factor is chemical compositions, mainly lipids, and amylopectins. The presence of lipids and amylopectins in flour can contribute to reducing Sol, SC, and WAC.

$\mathrm{SC}$, or known as a swelling index (SI), is the ability of starch to absorb water and swell, which is related to associative force in the starch granule (Godswill et al., 2019). SC value depends on particle size, compound composition, and processing methods (Chandra et al., 2015). It can be used as a guideline in the quality criteria of bakery products (Iwe, Onyeukwu, \& Agiriga, 2016). $\mathrm{SC}$ value of the UONFEF was significantly higher and longer than that of BONFEF $(p<0.05)$ (Table 2). The bleaching process of the ONFEF might reduce certain compounds in the flour related to the formation of hydrogen bonds such as certain carbohydrates (Nofiani et al., 2009).

WAC is defined as the amount of water absorbed in foodstuffs in limited water conditions to obtain the desired consistency and quality food products (Godswill et al., 2019). It can be used to describe the integrity of starch in aqueous dispersion, gelatinization index, crystallinity, product bulking, and consistency (Sharma, Singh, \& Singh, 2015; Jafari, Koocheki, \& Milani, 2017; Awolu, 2017). The WAC values of the UONFEF and OBNFEF were $145.1 \%$ and $145.6 \%$, respectively, which showed a significant difference (Table 2). Both WAC values were close to that of wheat flour, $140 \%$ (obtained maida or refined flour, India, (Chandra, 2013)), but different from that of commercial wheat flour (Golden

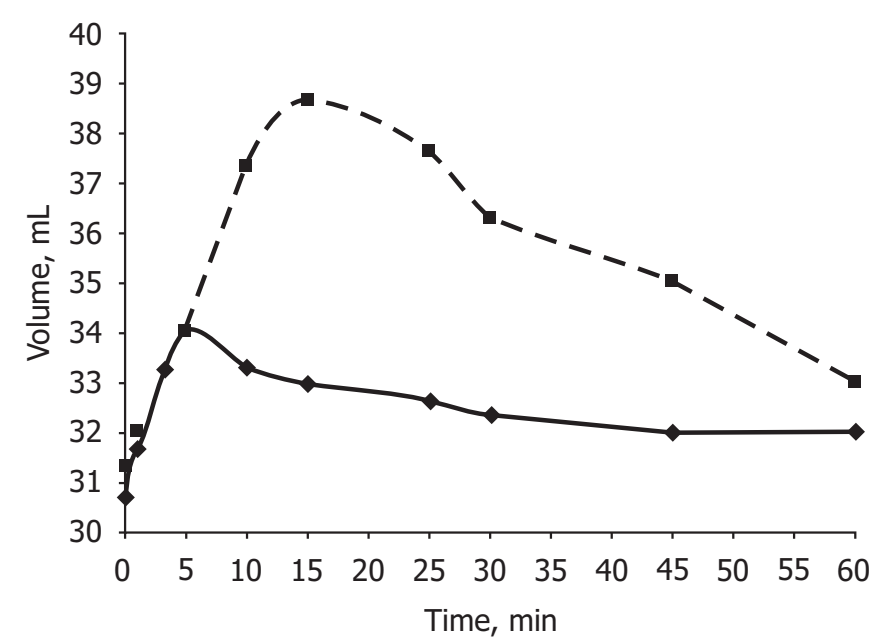

Figure 3. Swelling capacity of the UONFEF (solid line) and the BONFEF (dashed line)

Crown Brand) obtained from Nigerian Flour Mills Limited, Pourt Harcourt Nigeria namely $74.40 \%$ (KiinKabari, Eke-Ejiofor, \& Giami, 2015). The different WAC values among the two types of flour were caused by chemical compositions, processing, and their sources (Cornejo-Ramírez et al., 2018). In fact, WAC is affected by chemical compositions of foods, mainly hydrophilic parts (polar group) such as carbohydrates, fibers, protein contents, and protein denaturation, particle size (Chandra, 2013; Adams, Wireko Manu, Agbenorhevi, \& Oduro, 2019). The ability of polar groups to bind water contributes to increasing WAC value; for example, the presence of a high carbohydrate or fiber content may increase WAC value (Chandra, 2013; Sharma et al., 2015). Smaller particle size, particularly starch granules with a larger surface area, also increases WAC value.

BD or known as total solid content (TSC) parameter is important to find out the heaviness of solid samples and packaging requirements (Falade \& Christopher, 2015; Shafi, Baba, Masoodi, \& Bazaz, 2016). BD value is affected by particle size, starch content, moisture content, surface properties of flour or starch, and food material handling (Chandra et al., 2015; Shafi, Baba, 
Table 3. Sensory evaluation of cookies

\begin{tabular}{lccccc}
\hline \multirow{2}{*}{ Samples } & \multicolumn{4}{c}{ Criteria score of } & \multirow{2}{*}{ Overall criteria score } \\
\cline { 2 - 5 } & Taste & Color & Aroma & Texture & 0.30 \\
CWF & 0.30 & 0.26 & 0.31 & 0.32 & 0.36 \\
UONFEF & 0.37 & 0.37 & 0.35 & 0.35 & 0.34 \\
BONFEF & 0.32 & 0.37 & 0.34 & 0.33 & 0.22 \\
\hline Dominant criteria & 0.32 & 0.27 & 0.20 & & \\
\hline
\end{tabular}

CWF: Commercial wheat flour; UONFEF: Unbleached old nipah fruit endosperm flour; BONFEF: Bleached old nipah fruit endosperm flour

Masoodi, \& Bazaz, 2016; Das, Khan, Rahman, Majumder, \& Islam, 2019; Ngoma, Mashau, \& Silungwe, 2019). The larger the particle size, the higher the $\mathrm{BD}$ value. The $\mathrm{BD}$ value of the UONFEF was significantly higher than that of the BONFEF, and similar to that of the wheat flour (0.70-0.76 g/mL, obtained maida or refined flour, India) (Chandra, 2013; Awolu, 2017) (Table 2). However, BD value is the opposite of Sol, where the higher the BD value, the lower the Sol. It was probably caused by the particle size of the UONFEF, which was larger than that of the BONFEF (Figure 2). The other compounds (lipids, proteins, and ashes) contained on the surface of the UONFEF granules probably contributed to the particle size and shape of the UONFEF (Nofiani et al., 2009) (Figure 2). The UONFEF was categorized as high bulk density flour due to its BD value $>0.7 \mathrm{~g} /$ $\mathrm{mL}$ (Falade \& Okafor, 2015). High bulk density flour or starch could be used as thickeners in food products or the other application in food preparation; otherwise, low bulk density can be used in the formulation of complementary foods (Wijesinghe, Wicramasinghe, \& Saranandha, 2015; Chandra et al., 2015; Godswill et al., 2019).

A viscosifier is an agent that can increase viscosity. In food, this agent is important to stabilize food products such as emulsion, foam, and frozen dairy foods (Wang $\&$ Cui, 2005). Flour can be used as a viscosifier agent due to the swelling of the starch granules in the flour, and a higher amount of $\beta$-glucan, degradation of starch molecules (Kaur, Sharma, Singh, \& Dar, 2016). The viscosity of both the UONFEF and BONFEF showed insignificant differences (Table 2). Wheat flour viscosity was approximately 1.2 P.a.s for $10 \%$ solution, lower than both types of flour (1.2 P.a.s for $1 \%$ solution) (Kaur et al., 2016).

\section{Sensory Evaluation of Cookies}

The critical step in food product development is consumer's acceptability. Therefore, the sensory of the cookies product made from the UONFEF and the BONFEF was evaluated in terms of texture, taste, smell, and aroma. The priority criteria in the sensory evaluation from high to low criteria based on the panelists' acceptance were taste $(0.32)$, color $(0.27)$, texture $(0.22)$, and aroma $(0.20)$ attributes, respectively (Table 3). The taste sensory attribute is also reported to be more important than the other criteria for the sensory evaluation of cookies (Shafi et al., 2016). The taste attribute of the UONFEF cookies (0.37) received the highest score, which was significantly different from the others (Table 3). Each panelist gave a consistent assessment based on the consistency ratio value for all of the criteria (less than 10\%). The cookies made from the UONFEF were the most preferred cookies compared to the others (Table 3). However, the UONFEF was less preferred than the BONFEF based on the sensory evaluation. The UONFEF might develop a pleasant and specific aroma when it is baked. It can be seen that the UONFEF was awarded the first rank based on the aroma criteria by the panelists (Table 2 ). Therefore, the UONFEF could be used to replace the CWF in cookie production.

\section{CONCLUSION}

Flour can be successfully made from ONFEs using two treatments, namely unbleached (UONFEF) and bleached treatment (BONFEF). The functional properties of both types of flour showed a significant difference, the particularly optimum time of SC, WAC, and BD but no for the rendement, SP, and viscosity. Bleached treatment caused differences in terms of functional and physical properties (color and odor). The functional properties of UONFEF were significantly different from those of BONFEF except for the rendement, SP, and viscosity. The bleached treatment can increase the optimum time of SC, Sol, WAC values, and reduce the particle size. Besides, it could change the color of the UONFEF to be white and make it odorless. As a result, the UONFEF was more acceptable by panelists than the others. The cookies made from the UONFEF were the most preferred by the panelists than those from the 
others. Therefore, the UONFEF is the most suitable flour to make cookies.

\section{CONFLICT OF INTEREST}

The authors have no conflict of interest to declare.

\section{REFERENCES}

Adams, Z. S., Wireko Manu, F. D., Agbenorhevi, J., \& Oduro, I. (2019). Improved yam-baobab-tamarind flour blends: its potential use in extrusion cooking. Scientific African, 6, e00126. https://doi.org/10.1016/j.sciaf.2019.e00126

Akpabio, D. U., Essien, C. U., \& Eka, U. O. (2007). Chemical composition of the kernel Nypa fruticans (Nypa palm) and its application in confectionery preparation. Global Journal of Pure and Applied Sciences, 13(4), 513-516.

Amoo, A. R. N., Dufie, W. M. F., \& Ibok, O. (2014). Physicochemical and pasting properties of starch extracted from four yam varieties. Journal of Food and Nutrition Sciences, 2(6), 262. https://doi.org/10.11648/j.jfns.20140206.14

Anderson, R. A., Conway, H. F., \& Peplinski, A. J. (1970). Gelatinization of corn grits by roll cooking, extrusion cooking and steaming. Starch - Stärke, 22(4), 130-135. https://doi.org/10.1002/star.19700220408

Awolu, O. O. (2017). Optimization of the functional characteristics, pasting and rheological properties of pearl millet-based composite flour. Heliyon, 3(2), e00240. https://doi. org/10.1016/j.heliyon.2017.e00240

Bradley, L. R. (2014). Moisture and total solids analys. In Food Analysis (pp. 85-104). https://doi.org/10.1007/978-14419-1478-1

Buckman, E. S., Oduro, I., Plahar, W. A., \& Tortoe, C. (2018). Determination of the chemical and functional properties of yam bean (Pachyrhizus erosus (L.) urban) flour for food systems. Food Science and Nutrition, 6(2), 457463. https://doi.org/10.1002/fsn3.574

Chandra, S. (2013). Assessment of functional properties of different flours. African Journal of Agricultural Research, 8(38), 4849-4852. https://doi.org/10.5897/AJAR2013.6905

Chandra, S., Singh, S., \& Kumari, D. (2015). Evaluation of functional properties of composite flours and sensorial attributes of composite flour biscuits. Journal of Food Science and Technology, 52(6), 3681-3688. https://doi. org/10.1007/s13197-014-1427-2

Cornejo-Ramírez, Y. I., Martínez-Cruz, O., Del Toro-Sánchez, C. L., Wong-Corral, F. J., Borboa-Flores, J., \& CincoMoroyoqui, F. J. (2018). The structural characteristics of starches and their functional properties. CYTA - Journal of Food, 16(1), 1003-1017. https://doi.org/10.1080/19 476337.2018.1518343
Das, P. C., Khan, M. J., Rahman, M. S., Majumder, S., \& Islam, M. N. (2019). Comparison of the physico-chemical and functional properties of mango kernel flour with wheat flour and development of mango kernel flour based composite cakes. NFS Journal, 17(June), 1-7. https:// doi.org/10.1016/j.nfs.2019.10.001

Falade, K. O., \& Christopher, A. S. (2015). Physical, functional, pasting and thermal properties of flours and starches of six Nigerian rice cultivars. Food Hydrocolloids, 44, 478490. https://doi.org/10.1016/j.foodhyd.2014.10.005

Falade, K. O., \& Okafor, C. A. (2015). Physical, functional, and pasting properties of flours from corms of two Cocoyam (Colocasia esculenta and Xanthosoma sagittifolium) cultivars. Journal of Food Science and Technology, 52(6), 3440-3448. https://doi.org/10.1007/s13197-014-1368-9

Godswill, C., Somtochukwu, V., \& Kate, C. (2019). The Functional properties of foods and flours. International Journal of Advanced Academic Research / Sciences, 5(11), 2488-9849.

Iwe, M. O., Onyeukwu, U., \& Agiriga, A. N. (2016). Proximate, functional and pasting properties of FARO 44 rice, African yam bean and brown cowpea seeds composite flour. Cogent Food \& Agriculture, 2(1), 1-10. https:// doi.org/10.1080/23311932.2016.1142409

Jafari, M., Koocheki, A., \& Milani, E. (2017). Effect of extrusion cooking on chemical structure, morphology, crystallinity and thermal properties of sorghum flour extrudates. Journal of Cereal Science, 75, 324-331. https://doi. org/10.1016/j.jcs.2017.05.005

Kaur, G., Sharma, S., Singh, B., \& Dar, B. N. (2016). Comparative study on functional, rheological, thermal, and morphological properties of native and modified cereal flours. International Journal of Food Properties, 19(9), 1949-1961. https://doi. org/10.1080/10942912.2015.1089892

Kiin-Kabari, D. B., Eke-Ejiofor, J., \& Giami, S. (2015). Functional and pasting properties of wheat/plantain flours enriched with Bambara groundnut protein concentrate. International Journal of Food Science and Nutrition Engineering, 5(2), 75-81. https://doi.org/10.5923/j.food.20150502.01

Leach, H. W., \& Schoch, T. J. (1960). Structure of the starch granule. Cereal Chemistry, 38, 34-46.

Mir, S. A., \& Bosco, S. J. D. (2014). Cultivar difference in physicochemical properties of starches and flours from temperate rice of Indian Himalayas. Food Chemistry, 157, 448-456. https://doi.org/10.1016/j.foodchem.2014.02.057

Mursyid, M., \& Surhaini. (2018). Substitution of wheat flour with nypa flour to characteristics butter cake and acceptance of panelist. Indonesian Food Science \& Technology Journal, 2(1), 13-16. https://doi.org/10.22437/ifstj.v2i1.6413

Ngoma, K., Mashau, M.E., \& Silungwe, H. (2019). Physicochemical and Functional properties of chemically pretreated ndou 
sweet potato flour. International Journal of Food Science, 2019. https://doi.org/10.1155/2019/4158213

Nofiani, R., Romengga, J., \& Zahara, T. A. (2009). The Proximate composition of nipah palm starch (Nypa fruticans Wurmb). International Collaboration for Handling Global Crisis, 195-201.

Okaka, J. C., \& Potter, N. N. (1977). Functional and storage properties of cowpea powder-wheat flour blends in breadmaking. Journal of Food Science, 42(3), 828-833. https://doi.org/10.1111/j.1365-2621.1977.tb12614.x

Prasad, N., Yang, B., Kong, K. W., Khoo, H. E., Sun, J., Azlan, A., Ismail, A., \& Romli, Z. B. (2013). Phytochemical and Antioxidant capacity from Nypa fruticans Wurmb. Fruit. Evidence-Based Complemetary and Alternative Medicine, 1-9.

Sasaki, T., \& Matsuki, J. (1998). Effect of wheat starch structure on swelling power. Cereal Chemistry, 75(4), 525-529. https://doi.org/10.1094/CCHEM.1998.75.4.525

Shafi, M., Baba, W. N., Masoodi, F. A., \& Bazaz, R. (2016). Wheat-water chestnut flour blends: effect of baking on antioxidant properties of cookies. Journal of Food Science and Technology, 53(12), 4278-4288. https:// doi.org/10.1007/s13197-016-2423-5

Sharma, S., Singh, N., \& Singh, B. (2015). Effect of extrusion on morphology, structural, functional properties and in vitro digestibility of corn, field pea and kidney bean starches. Starch/Staerke, 67(9-10), 721-728. https:// doi.org/10.1002/star.201500021
Subiandono, E., Heriyanto, N. M., \& Karlina, E. (2016). Potensi nipah (Nypa fruticans (Thunb.) Wurmb.) sebagai sumber pangan dari hutan mangrove. Buletin Plasma Nutfah, 17(1), 54. https://doi.org/10.21082/blpn.v17n1.2011. p54-60

Tomlinson, P. B. (2016). Family: Arecaceae (Palmae). In The Botany of Mangroves. Retrieved from https://doi. org/10.1017/CBO9781139946575.016

Ulyarti, Nazarudin, \& Sari, D. W. (2017). The study of functional properties of Nypa fruticans flour. AIP Conference Proceedings, 1823(March). https://doi. org/10.1063/1.4978100

Wang, Q., \& Cui, W. S. (2005). Food carbohydrates: Chemistry, Physical Properties and Applications. In W. S. Cui (Ed.), Food Chemistry (Vol. 11, pp. 77-78). https:// doi.org/10.1016/0308-8146(83)90118-8

Wijesinghe, J. A. A. C., Wicramasinghe, I., \& Saranandha, K. H. (2015). Kithul flour (Caryota urens) as a potential flour source for food industry. American Journal of Food Science and Technology, 3(1), 10-18. https://doi. org/10.12691/AJFST-3-1-2

Yu, S., Ma, Y., Menager, L., \& Sun, D. W. (2012). Physicochemical Properties of starch and flour from different rice cultivars. Food and Bioprocess Technology, 5(2), 626-637. https:// doi.org/10.1007/s11947-010-0330-8 